\title{
The Emergence of Amish Genetic Studies: A Brief History of Collaboration and Reciprocity
}

\author{
Steven M. Nolt \\ Professor of History and Anabaptist Studies \\ Young Center for Anabaptist and Pietist Studies \\ Elizabethtown College \\ nolts@etown.edu
}

\begin{abstract}
Since the 1960s, Amish genetic studies has become a significant arena of collaboration between medical researchers and Old Order Anabaptists. This article describes the origins of and early actors in this field of research and pushes beyond the handful of cursory accounts that focus exclusively on Dr. Victor McKusick, central though he was, to include the critical contributions of other researchers, physicians, and Amish liaisons. The collective work of these individuals quickly pointed to four areas of ongoing inquiry: the cultural context of health and illness, documentation of known but very rare conditions, identification of previously undocumented conditions and diseases, and demography. A remarkable feature of this early research was its interdisciplinary nature and its collaborative engagement with Amish people. That collaboration resulted not only in numerous medical breakthroughs, but also in expanded settlement directories and updated family genealogies, which Amish communities embraced, replicated, and came to regard as valuable community resources.
\end{abstract}

Submitted May 5, 2020; accepted June 5, 2020; published September 18, 2020

https://doi.org/10.18061/jpac.v1i1.7659

Keywords: genetic studies; Amish health; demography; McKusick, Victor A; Egeland, Janice A; Cross, Harold E.

\footnotetext{
$\mathrm{G}$ enetic studies involving Amish populations has become a remarkable area of collaboration between medical researchers and Old Order Anabaptists. This partnership, an unlikely one from some perspectives, brings together scientists operating on principles of empirical investigation and rational inquiry with Amish church members committed to tradition and an acceptance of divine will. Yet the relationship thrives as geneticists benefit from working with defined populations in possession of comprehensive genealogies that make possible the reconstruction of pedigrees involving large families and multiple generations, and Amish parents and grandparents sense that the research holds the potential to benefit loved ones born with conditions that are painful or lethal. Amish motivation is also fueled by a desire to help others, since they know that findings may aid countless people in wider society. Noting the depth of Amish altruism, researchers report that parents invited to join new investigations almost uniformly
} 
"commented that [although] our studies may not necessarily help their affected children ... they were happy to participate nonetheless because of the potential benefit to others."

Whether direct or indirect, immediate or at arm's length, relationships have been a critical feature of this work. Collaboration and reciprocity between and among researchers and with Amish families and communities has characterized genetic studies as it developed in the 1960s. The focus here is not on charting all the discoveries and publications stemming from this research, which have grown well beyond any manageable bibliography, as was still somewhat possible in 1978 with the appearance of Medical Genetic Studies of the Amish: Selected Papers. ${ }^{2}$ Rather, this essay gives attention to the collaborative roots of this research, both in its collegial engagement with Amish participants and as it exemplified interdisciplinary partnership among scholars and practitioners. In this sense, the field is an example of the importance of relationships in achieving advances in community health, medical research, and patient care and well-being.

\section{Context and early efforts}

Genetics was something of a sideline endeavor in medical schools of the 1950s. The long shadow cast by the disgraced eugenics movement and the horror of Nazi "race science" had rendered interest in human genetics somewhat suspect, though that judgement was beginning to change. ${ }^{3}$ The first International Congress of Human Genetics, held in Copenhagen in 1956, just a few years after the organization of the American Society of Human Genetics, marked the beginning of a shift in perception, though that shift is perhaps clearer in hindsight than it was at midcentury. Amish genetic studies would become a novel endeavor in a novel field, emerging in a context in which "institutions, disciplines, practices, and ideas ... began to reconfigure human disease in genetic terms." 4

An early example of such reconfiguring was the establishment in the mid-1950s of programs and protocols for screening for the treatable genetic metabolic disorder phenylketonuria (PKU). ${ }^{5}$ In Elkhart County, Indiana, for example, the county's energetic chief health commissioner, Dr. David H. Martin (1899-1976), who had a penchant for research despite the limitations of his local office, partnered with the newly formed (1956) Department of Human Genetics at the University of Michigan to create home test kits to screen homebirthed newborns for PKU. The program began in August 1961 and revealed a handful of positive results, all clustered in several related Amish households. Martin's findings were eventually published, but were noted as much for demonstrating the value of low-cost, home testing as for their Amish subjects. ${ }^{6}$

\footnotetext{
${ }^{1}$ Cross and Crosby, "Amish Contributions to Medical Genetics," 463.

${ }^{2}$ McKusick, Medical Genetic Studies of the Amish.

${ }^{3}$ Lindee, Moments of Truth, 1-2, 9-11.

${ }^{4}$ Lindee, 1.

${ }^{5}$ Lindee, 28, 45-46. See appendix for definitions of select medical terms and conditions mentioned in this article.

${ }^{6}$ Martin, "PKU: A Casefinding Project." Martin's newborn PKU testing system drew notoriety for its simplicity; see Free and Free, "Self-Testing," 832. Among the examples of Martin's involvement with
} 
Around the same time that Martin found an unusual prevalence of PKU in the northern Indiana Amish community, doctors working in another Indiana settlement published what was likely the first scientific paper involving genetics and the Amish. Physicians at the Caylor-Nickel Hospital in Bluffton, Indiana, identified a type of autosomal recessive limb-girdle muscular dystrophy in seven so-called "Swiss Amish" families in nearby Adams County. Their preliminary findings appeared in 1961 in the journal Pediatrics, and more detail followed in 1968 and $1970 .^{7}$

Given the new scientific and public policy energy coalescing around genetics in the late 1950s, it is not surprising that these Indiana Amish studies appeared in the medical literature when they did. No doubt, given more time, occasional new publications would have gradually contributed to the scholarly discussion. ${ }^{8}$ But events did not unfold gradually. Instead, a series of interrelated, serendipitous events precipitated, quite quickly, a whole series of Amish genetics investigations within just a few years.

\section{Serendipity in 1962}

Central to the story of sudden scholarly convergence was Victor A. McKusick, M.D. (1921-2008), who was emerging as a principal figure in genetics in the United States. In 1960, McKusick was a cardiologist and professor at the Johns Hopkins School of Medicine. The school itself still had no department of genetics, but McKusick had developed some expertise in the subject via his study of inherited connective tissue disorders affecting the hearts of his cardiac patients. In 1956, he had been one of the American presenters at the Copenhagen Congress of Human Genetics, and the next year, when he was named director of Hopkins's chronic disease clinic, he established a division of medical genetics within that clinic, arguing that heritable conditions are, by definition, chronic. That division, within what was renamed the Moore Clinic, became his primary research base. He was soon directing an annual summer short course in medical genetics, and by 1966, he had published the first edition of the seminal work, The Mendelian Inheritance in Man. ${ }^{9}$

Important as McKusick was, when it came to Amish genetics, he was not a solo actor. ${ }^{10}$ Essential to his work were a number of people who, in unexpected ways, introduced him to the

academic research, in this case with Cornell University and traffic safety, is one noted in "Death of Boy Raises Toll in Crash to 6," The Anderson (IN) Herald, Jan. 24, 1956, 16.

${ }^{7}$ Jackson and Carey, "Progressive Muscular Dystrophy."

${ }^{8}$ E.g., Juberg, "Polymorphisms in an Amish Isolate."

${ }^{9}$ One of many biographical sketches of McKusick is on the National Institutes of Health U.S. National Library of Medicine website accompanying the McKusick papers index, https://profiles.nlm.nih.gov/spotlight/jq/feature/biographical-overview.

${ }^{10}$ McKusick's account of his "discovery" of the Amish includes references to Hostetler and Krusen, but contemporary sources and later interviews make clear it was a more richly populated story. See McKusick's memory in McKusick, Medical Genetic Studies, ix, and Francomano, "Victor A. McKusick." Lindee, Moments of Truth, devotes an entire chapter to McKusick's work with the Amish, and on pp. 6465 suggests researchers should take a more critical view of McKusick's own narrative, yet Lindee's chapter largely accepts McKusick's version of events with no attention to the foundational work of Egeland, or the critical roles of Cross and the Amish liaisons. 
Amish in 1962. That year, he encountered anthropologist John A. Hostetler, family physician David E. Krusen, medical student Harold E. Cross, and sociologist Janice A. Egeland.

In 1962, McKusick's university service including sitting on the faculty board that advised the Johns Hopkins University Press by reviewing prospective book manuscripts the press was considering. The board had just received a manuscript by John A. Hostetler (1918-2001), a Penn State Ogontz (now Penn State Abington) professor of anthropology. Hostetler, who had been raised in an Amish home in Big Valley, Pennsylvania, and Kalona, Iowa, would become a leading academic authority on the Amish. In 1962, the Amish were still the subject of relatively few scholarly studies and McKusick found the manuscript intriguing. The faculty board recommended publication, and the book became Hostetler's classic Amish Society (1963). ${ }^{11}$

Hostetler's book particularly interested McKusick because the doctor had, only a few weeks earlier, come across a glossy pharmaceutical advertising piece — a "throw away piece," he later called it - that mentioned, of all things, the Amish. The mailer featured a human interest story (presumably intended to hook recipients before they threw the mailer away!) about David Krusen, a country doctor whose house-call practice included Amish patients with achondroplasia (dwarfism). As a connective tissue disorder, achondroplasia was of interest to McKusick, and he noted the article. But now, having read Hostetler's manuscript and its description of endogamous Amish populations stemming from a limited number of immigrants, McKusick wondered if Krusen's patients actually had achondroplasia, which is autosomal dominant, or if, given the population Hostetler's manuscript described, they might instead be exhibiting a different and less common recessive disorder. McKusick made a mental note to visit Krusen and arranged to meet Hostetler.

Meanwhile, a second-year Hopkins medical student, Harold E. Cross, who was a native of Elkhart County, Indiana, received a newspaper clipping from his mother, who still lived there, reporting on Elkhart's health commissioner, David Martin, finding higher rates of PKU among the county's Amish population. Cross, whose family was of Amish heritage, had several cousins with intellectual disabilities and Cross's mother thought he would be interested in the story. Cross had heard of McKusick's work in genetics, so he stopped by McKusick's faculty office with the clipping. The professor expressed great interest in it and in Cross's extensive knowledge of midwestern Amish communities, and he invited Cross to join him for an upcoming dinner with Hostetler to discuss the possibilities of Amish research. ${ }^{12}$

Conversations with Hostetler and Cross convinced McKusick of the utility of the Amish community for genetic study. Hostetler could advise his forays into Lancaster County,

\footnotetext{
${ }^{11}$ John A. Hostetler, Amish Society, 276, includes a footnote on the work of Egeland and McKusick. See also a citation to Egeland's dissertation in process (it would be finished in 1967) on p. 330. On Amish scholarship prior to Hostetler, see Donnermeyer, "Of Shoulders and Shadows."

${ }^{12}$ Harold E. Cross, telephone interview by the author, Feb. 25, 2020. Both of Cross's parents were of Amish background, though most members of their and his generations became Amish-Mennonites or Conservative Mennonites; one of Harold's first cousins, Mahlon Cross, Jr. (1937-2017), remained Old Order Amish his entire life.
} 
Pennsylvania, which was only a couple hours journey from Baltimore, but Krusen and Egeland would prove essential gatekeepers. David Krusen, M.D. (1922-2000), the Paradise, Pennsylvania, family physician who had been the focus of the pharmaceutical mailer, introduced McKusick to several of his Amish patients with dwarf characteristics. Krusen was a beloved local doctor who had attended countless homebirths and was deeply involved in community organizations and with Amish schools and rural public schools that still enrolled some Amish students. ${ }^{13}$ Perhaps more important, though figuring less prominently in McKusick's later memories of 1962, was Janice Egeland. In 1962, Egeland, who had a background in molecular biology and public health, was teaching at Lancaster's Franklin and Marshall College while finishing her dissertation at Yale in medical sociology. For the previous two years, Egeland had been doing fieldwork, fulltime, in the Lancaster Amish settlement, charting Amish understandings of health and access to health care. ${ }^{14}$ Her research involved a representative sample of the entire settlement and thus was geographically wider than Krusen's Leacock Township practice. Egeland's deep friendship with a number of Amish women, especially Mary Ann Riehl (1930-2009), had allowed her to accumulate trusted connections across the community, and her interest in pedigree meshed with Amish interest in genealogy and family. ${ }^{15}$

Like Krusen, Egeland had also noticed the presence of dwarfism, and she had collected Amish accounts of how the condition ran in certain families and had begun to construct relevant pedigrees. On one trip back to Yale, Egeland had suggested to a professor at Yale's medical school that the Lancaster Amish would be a good case study of heredity, but he dismissed her observations since she was not a medical doctor and perhaps, she surmised, because she was a woman. Hearing that McKusick was interested in the Amish, Egeland telephoned the Moore Clinic to discuss her observations. McKusick took her seriously and quizzed her about patient conditions such as polydactyly and atrial septal defect, which would suggest a condition other than achondroplasia. Within two days of that call, Egeland later recalled, McKusick was in Lancaster, driving around the county with her to visit numerous families. ${ }^{16}$ Under the aegis of the Moore Clinic, McKusick

\footnotetext{
13 "Dr. Krusen Takes Down Shingle After 39 Years at the Bedside of Paradise," Lancaster (PA) New Era, Aug. 24, 1987, 1, 18; David E. Krusen obituary, Intelligencer Journal (Lancaster, PA), Aug. 23, 2000, B3. Krusen had practiced in Paradise since his graduation from Hahnemann Medical School in 1948. The 1987 newspaper story included photos of Krusen and Amish children with captions stating the pictures had appeared in a 1963 pharmaceutical publication. If this is the publication McKusick recalled, the date must be 1962, the date to which evidence from multiple sources points.

${ }^{14}$ Johanna Grimes, "A New Look at Our Amish Community," Lancaster (PA) New Era, July 27, 1967, 1-2, and "Author Lived with Amish for Two Years," Lancaster (PA) New Era, July 27, 1967, 2. Egeland credited Irving Hallowell, her University of Pennsylvania public health professor, for suggesting that she study Amish society; see p. ii in Janice A. Egeland, "Belief and Behavior." See also transcript of C. Max Lang interview with Janice A. Egeland, Sept. 1, 2010, archived in the Pennsylvania State University ScholarSphere, https://scholarsphere.psu.edu/concern/parent/5712mg885/file_sets/rr494vk831.

${ }^{15}$ Egeland, "Belief and Behavior," ii. Riehl, who was a neighbor and friend of the author's family, often expressed deep appreciation for Egeland.

16 Transcript of Lang interview with Egeland, 4-5.
} 
arranged blood sampling and interviews in the Lancaster settlement, employing not only Egeland and Riehl, but also Sara E. Fisher (1928-2007), an Amish woman whose energy, directness, and sense of humor struck every "English" person with whom she worked. Fisher would become a longstanding Moore Clinic field employee whose Old Order sensibilities and natural inquisitiveness would bridge Amish and scientific worlds for countless people. ${ }^{17}$

Based on this background work, McKusick began extensive fieldwork designed to identify conditions among the Amish of southeastern Pennsylvania, primarily in the Lancaster community. Following the addition of Cross to the Moore Clinic staff, he and McKusick made an exploratory trip to Holmes County, Ohio, in the summer of 1964 to meet with local physicians and Amish leaders. Finding considerable interest among both groups to study this large settlement and its familial conditions, McKusick suggested that Cross survey the Amish in the community, focusing on neurological conditions. Over the next three years, Cross, with significant assistance from Elton D. Lehman, D.O. (1935-2016), collected medical and family information on more than 200 individuals. $^{18}$

The role of Amish liaisons, as well as the trust engendered by Egeland and Krusen, were undoubtedly critical to these early studies' breadth and success. So, too, was Cross's status as a doctor whose first language was Pennsylvania Dutch and whose familiarity with the northern Indiana world of his childhood was matched by his family's roots in Holmes County, Ohio. By all accounts, McKusick respected Amish values, including their refusal to limit family size simply because of potential congenital abnormalities. ${ }^{19} \mathrm{He}$ explained that he went "to them as a physician ... genuinely concerned about those among them who are physically and mentally handicapped" and "prepared to use all the resources at our disposal to help them with their health problems." 20 But he and his team allowed Amish families to define those health problems, and Amish liaisons were apparently crucial in this regard. ${ }^{21}$

\section{The Outlines of Research}

The remarkable convergence of experience, sensibilities, and expertise in 1962 quickly generated a clutch of publications that pointed to a quartet of concerns: (1) the cultural context of health and illness, (2) documentation of known but very rare conditions, (3) identification of previously undocumented conditions and diseases, and (4) demography.

\footnotetext{
${ }^{17}$ Francomano, "Victor A. McKusick," 122, pays tribute to Fisher.

${ }^{18}$ Cross, "Genetic Studies in an Amish Isolate"; Cross, e-mail message to the author, Mar. 8, 2020.

${ }^{19}$ Cross, telephone interview.

${ }^{20}$ McKusick, Medical Genetic Studies, x.

${ }^{21}$ Egeland and the Amish liaisons apparently played key roles in this regard; see transcript of Lang interview with Egeland, and the approach revealed in Egeland, "Belief and Behavior."
} 
In 1964, McKusick, Hostetler, and Egeland published "Genetic Studies of the Amish: Background and Potentialities." 22 The essay laid out its argument for engaging the Amish by presenting 15 reasons Old Order society offered such promise. Some of the points related to the self-defined, closed nature of the community. Other factors involved the group's relative sociocultural uniformity in standard of living, occupations, and access to medical care. The authors also cited pragmatic reasons, including the availability of genealogies and adequate genetic variation, between, say, Pennsylvania and Ohio, to make comparison of isolates possible. Although the essay was structured as a justification for investigating Amish genetics, its attention to the anthropology of illness and the interdisciplinary collaboration among the three authors suggested the necessity of understanding culture, alongside genes, in promoting Amish health and wellbeing.

Two articles, in 1964 and 1965, focused especially on the variations of dwarfism to which Krusen and Egeland had introduced McKusick. One of those essays presented considerable new data on a recognized but rare condition: the Ellis-van Creveld syndrome. The article essentially doubled the number of cases in the scholarly literature and became a classic. ${ }^{23}$ Egeland's experience with Amish genealogies proved critical in the genetics section of the paper. The journal was in the galley proof stage when she convinced the Moore geneticists that the Ellis-van Creveld founder within the Amish world was not an immigrant surnamed Fisher, as the Hopkins' model originally suggested, but Samuel King (1724-1777). ${ }^{24}$ That piece of pedigree pointed future researchers in fruitful directions. In a second article, titled "Dwarfism in the Amish, Part II," McKusick, Hostetler, Egeland, and two fellows in genetics at Hopkins presented findings on a previously unknown condition — cartilage-hair hypoplasia. ${ }^{25}$

Finally, Cross and McKusick began publishing work on Amish demography, based on Cross's comprehensive study of the Holmes County, Ohio, Amish settlement. ${ }^{26}$ Upon receiving his M.D. degree in 1964, Cross had immediately enrolled in the first cohort of Johns Hopkins's new human genetics Ph.D. program, undertaking extensive fieldwork in Ohio that included collecting data on age and sex distribution, occupations, marriage, parity, and birth intervals. As a native Pennsylvania Dutch speaker, Cross approached families on their own linguistic terms, which "led to easy conversations and lots of discussions." ${ }^{27}$ Cross was not the first to undertake Amish demography, but his project was larger in scope and scale than any that had preceded it. Assisted

\footnotetext{
${ }^{22}$ A companion piece, authored by McKusick, Hostetler, Egeland, and Roswell Eldridge, who was a fellow in genetics at Johns Hopkins, was "The Distribution of Certain Genes in the Old Order Amish," published in Cold Spring Harbor Symposia on Quantitative Biology.

${ }^{23}$ McKusick, Egeland, Eldridge, and Krusen, "Dwarfism in the Amish, Part I."

${ }^{24}$ Transcript of Lang interview with Egeland, 5.

${ }^{25}$ McKusick, Eldridge, Hostetler, Ruangwit, and Egeland, "Dwarfism in the Amish, Part II." This article and the earlier publication on the Ellis-van Creveld Syndrome acknowledge dozens of family doctors in the Lancaster, Pennsylvania, settlement for sharing observations and experience.

${ }^{26}$ Cross and McKusick, "Amish Demography."

${ }^{27}$ Cross, telephone interview; Cross, e-mail message to the author, Mar. 7, 2020.
} 
by Beulah Stauffer Hostetler (1926-2005), spouse of John A. Hostetler, and using new data manipulation software, Cross collected demographic information on the entire Holmes County settlement of over 9,000 individuals and generated a complete genealogy of the settlement that compared with the one Egeland was creating for Lancaster County. ${ }^{28}$

\section{A Two-Way Street: Genealogies and Settlement Directories}

As observers have long recognized, Amish participants in genetic studies are quick to name the medical benefits they perceive to accrue to their families and communities, as well as the ways such studies help others. Less often noted is the demographic data that came back to Amish communities in the form of genealogies and settlement directories generated by the 1960s genetic studies. Originally produced and largely paid for by the Moore Clinic at Johns Hopkins, often with National Institutes of Health subsidy, these books were quickly embraced by the Amish, who have continued to update and reissue them.

Genealogies. Early genetics projects augmented existing Amish genealogies. In Ohio, Beulah Hostetler and Cross connected, combined, and added to six family histories that had been published between 1892 and 1955. Their 160-page book was issued in 1967 as The Ohio Amish Genealogy. ${ }^{29}$ In Lancaster County, Janice Egeland updated and expanded a 1957 Fisher genealogy to produce Descendants of Christian Fisher and Other Amish-Mennonite Pioneer Families, which was underwritten and published by the Moore Clinic in $1972 .{ }^{30}$ Family members, in turn, updated and reissued the Fisher book in 2009. The book remains popular; as one Amish man dryly noted, it is "just about up there with the Ausbund and the Martyrs Mirror in our circles." 31

\footnotetext{
${ }^{28}$ Harold E. Cross, Ohio Amish Genealogy. The genealogy also appeared as part D of volume 2 of Cross's dissertation.

${ }^{29}$ Cross, Ohio Amish Genealogy, iii: "The genealogy contains the ancestors of all married couples [in the settlement] ... traced, as completely as possible, to the immigrants who arrived in this country from Europe in the 18th and 19th centuries." See also the 400-page reference, Cross and Hostetler, Index to Selected Amish Genealogies.

${ }^{30}$ Egeland, Descendants of Christian Fisher.

${ }^{31}$ A handful of Lancaster Amish opposed Egeland's update of the Fisher book, but those opponents were provoked not by particularly Amish concerns, but by the influence of a Dunkard Brethren itinerant, Ernest L. Miller (1898-1984), of Harrisonburg, Virginia, who briefly held some influence over a number of Amish households in two Lancaster church districts. Miller was a heath food advocate, strident anticommunist, and ardent premillennialist. His Truth Crusader newsletter promoted the idea that agents of the Soviet Union were compiling lists of Christians for execution following a prophesied Soviet invasion of the United States in 1966. Prodded by Miller, several Amish households were frantic to be removed from the Fisher book, thereby "keeping their names off the extermination list." After Miller's predictions failed to materialize, concerns about the genealogy subsided. The larger point here is the overwhelming Amish appreciation for the directories and genealogical work done by Egeland, Cross, Hostetler, and others. See Egeland, "Belief and Behavior," 275-82; quote is from p. 282.
} 
Settlement directories. A handful of community compendia existed before the mid-1960s, but these were often simply lists of household heads without addresses, demographic detail, or maps. ${ }^{32}$ In 1964, Cross began partnering with Ervin N. Gingerich (1916-2007), a Holmes County, Ohio, deacon who had maintained a list of Ohio household heads, to expand that list into a comprehensive directory. The resulting volume, issued in 1965, listed birth and marriage dates, all children and married children's spouses, and occupations of heads of household. There was a brief settlement history by Amish historian Leroy Beachy, along with listings of parochial schools and their teachers. Church district maps located each family geographically, and two indexes listed men and women, with women alphabetized by their family-of-origin surname. ${ }^{33}$ All of these features would become staples of Amish directories in the years to come. ${ }^{34}$ The book was published by the Division of Medical Genetics, Johns Hopkins University Hospital, and Cross was listed as the directory's editor.

Next, Cross worked with Eli Gingerich (1915-2005), of Middlebury, Indiana, to prepare a directory for the Elkhart-LaGrange settlement. Gingerich, who had served as the first Amish teacher in Indiana's first Amish school, was a well-known figure in the community and coordinated the collection of much of the data. ${ }^{35}$ Published in 1970 by Johns Hopkins, the Indiana directory was similar to its Ohio predecessor and included "an extensive list of Amish clergy from the beginnings of this Amish community to the present" as well as "the recent origin and growth of the Amish parochial school system." Editor Cross "hoped that they [Amish community members] will find in it a reflection of their rich heritage and a basis for continued belief in their unique identity." "36 In a separate preface, Gingerich explained that the directory aimed to be "a reliable source for birth, death and marriage dates, as well as a handy reference for addresses and home sites," and expressed thanks for "cooperation [with] the Division of Medical Genetics at The Johns Hopkins Hospital at Baltimore, Maryland. They have the much greater task and I wish them success in their study of better understanding and treating unusual illnesses found among society as a whole." 37

\footnotetext{
${ }^{32}$ For example, Ohio Amish Directory and Amish Farm and Home Directory listed married adults and ministers. Old Order Amish Church Districts of Indiana, compiled by Levi D. Christner was a collection of district maps without household names.

${ }^{33}$ Cross and Ervin Gingerich, Ohio Amish Directory. The directory also appeared as part B in volume 2 of Cross's dissertation.

${ }^{34}$ Districts associated with the Swartzentruber and Stutzman affiliations did not provide information for the directory, a pattern that has continued through subsequent editions of the directory. Today, many Swartzentruber settlements beyond the Holmes and Wayne Counties areas participate in statewide directories or have issued their own settlement directories.

${ }^{35}$ Cross and Eli Gingerich, Indiana Amish Directory. Eli Gingerich taught at Plain View School, Middlebury, Indiana, 1949-1951. The school opened in 1948 and for one year employed a non-Amish, retired public school teacher. Gingerich resigned from teaching when he was ordained a minister in 1951.

${ }^{36}$ Cross and Eli Gingerich, Indiana Amish Directory, iv.

${ }^{37}$ Cross and Eli Gingerich, iii.
} 
In 1973, the Moore Clinic's division of medical genetics, now led by David R. Bolling, worked with Ervin Gingerich to publish a new edition of the Holmes County directory and a first edition of a Geauga County, Ohio, directory. ${ }^{38}$ Subsequent directories in these and other settlements were underwritten by the Amish themselves, though they followed the original Hopkins format and, in some cases, coordination of new editions remained with the families with whom Cross had initially worked. $^{39}$

By the 1980s, settlement directories had become central pillars of Amish community life and identity in many places. The books included sections on local history, schools, and schoolteachers, and lists of minsters, all of which contributed to community identity and solidarity. Today, settlement directories are commonplace and well worn, regarded as nearly essential community handbooks. Some Amish individuals have commented to the author that they don't know how they lived before the advent of directories. ${ }^{40}$ The demographic information that Amish households provided researchers in the 1960s was given back to the churches in the form of collaboratively produced volumes, quickly embraced by community members. The scores of Amish-produced directories and genealogies that have followed, imitating those of the early Hopkins studies, continue to bear witness to the mutuality inherent in those projects.

\section{The Story Continued}

Genetic studies involving Amish populations were not, of course, limited to the circle of academics and Amish who came together in the early 1960s. Studies continued to emanate from McKusick's clinic at Johns Hopkins, but others emerged from the University of Michigan and from other institutions. By 1978, when McKusick published Medical Genetic Studies of the Amish, the collection identified 16 newly recognized genetic disorders, 18 previously recognized but now better understood disorders, as well as contributions to immunogenetic studies, chromosomal variations, and analyses of common disorders in areas such as blood pressure and diabetes. ${ }^{41}$

\footnotetext{
${ }^{38}$ The 1973 Holmes County directory listed Ervin Gingerich as editor and said, "Published by Division of Medical Genetics, Johns Hopkins University School of Medicine.” Likewise, the title page of the 1973 Geauga County directory indicated, "Published by Division of Medical Genetics, Johns Hopkins University School of Medicine."

${ }^{39}$ The 1981 Holmes County and vicinity directory was published locally by Schlabach Printers. In the preface, Ervin Gingerich noted (p. v) that John Hopkins had been "responsible for editing and bearing part of the printing cost" for previous editions of the directory, "for making studies of Hereditory [sic] diseases and tendencies that may run in families, and for better understanding of how to deal with them," but that this edition was not subsidized and, thus, cost more. In Indiana, Eli Gingerich and then his son-inlaw Jerry Miller, continued producing the Elkhart-LaGrange settlement directories.

${ }^{40}$ By 2020, Amish communities have published scores of settlement directories, some covering a single location, others including multiple settlements within a single state, and still others combining settlements of a single affiliation across many states. Early directories unconnected to Johns Hopkins include the first editions of directories for the Nappanee, Indiana, and Adams County, Indiana, settlements, both published in 1968.

${ }^{41}$ McKusick, Medical Genetic Studies, v-vii. One hundred seven authors are represented in the collection. Cross, Egeland, and Charles Jackson follow McKusick in quantity of citations.
} 
By that time, McKusick himself was involved with genetic research that was much bigger than the Amish, and he was developing what would become the Human Genome Project. Meanwhile, Janice Egeland, after working for three years as a fellow in genetics at Johns Hopkins, became a founding faculty member at Penn State Hershey School of Medicine and focused her efforts on understanding the genetics of bipolar disorder. In 1974, she moved that project to the department of psychiatry at the University of Miami. ${ }^{42}$ In the late 1960s and early 1970s, medical genetics was still largely a laboratory-based branch of medicine and Harold Cross decided that he "wanted to see people, to work with patients" in a way that genetics, at the time, didn't allow, since "there was no genomic sequencing and it was more about understanding conditions than treating people." Consequently, he returned to medicine and completed a residency in ophthalmology. Later, as a faculty member at the University of Arizona, his twin interests reconnected with work on hereditary conditions of the eye and a new generation of Amish research around the so-called Mast and Troyer neurological syndromes that he had first identified in the 1960s. ${ }^{43}$

For their part, Amish liaisons Sara Fisher and Mary Ann Riehl continued to play roles as contacts and coordinators for new and ongoing genetic studies. For neither woman was involvement with genetic studies a permanent, fulltime job. Fisher was, for many years, also an Amish schoolteacher and a typist and copy editor for the monthly Amish magazine The Diary, but in 1985 when she wrote a short book about Amish schools, she listed her Johns Hopkins work prominently in the "about the author" section. ${ }^{44}$ Riehl, who was less outspoken than Fisher, nevertheless quietly cut an unusual Amish profile, taking the bus each day from her home east of Lancaster to her job working in the lab at Lancaster General Hospital. She read voraciously and recommended books of all sorts to friends and neighbors. ${ }^{45}$

Developments in Amish genetic studies in more recent decades - as well as Mennonite and Hutterite studies - are beyond the scope of this essay, but they include renewed attention, on one hand, to pediatric diagnosis and intervention of rare conditions, and, on the other hand, to research and therapies related to more common and adult diseases, such as hypertension and diabetes. Since 1989, the work of D. Holmes Morton, M.D., and the Clinic for Special Children near Strasburg, Pennsylvania, has been associated with the former emphasis, and the investigations of Alan Shuldiner, M.D., and the University of Maryland's Amish Research Clinic has been representative of the latter, though the field is richly populated by many more clinicians and researchers. ${ }^{46}$

\footnotetext{
42 "Hershey Med School Adds Dr. Egeland," Intelligencer Journal (Lancaster, PA), June 15, 1967, 22; transcript of Lang interview with Egeland, 6, 10-11.

${ }^{43}$ Cross, telephone interview. Cross and Crosby, "Amish Contributions to Medical Genetics," 455-57, includes citations to earlier (1967) publications on the Mast and Troyer syndromes.

${ }^{44}$ Fisher, The Amish School, 96; Sara E. Fisher obituary, Lancaster (PA) New Era, Apr. 11, 2007, B8. ${ }^{45}$ Mary Ann Riehl obituary, Lancaster (PA) New Era, Apr. 27, 2009, B3. In the early 1990s, the author provided "taxi service" for Riehl, who eagerly shared her current reading list and book recommendations, which could include everything from Christian devotional works to a biography of Israeli pacifist and violinist Joseph Abileah.

${ }^{46}$ Francomano, McKusick, and Biesecker, "Medical Genetic Studies of the Amish"; Cross and Crosby, "Amish Contributions to Medical Genetics," 463-67.
} 
Meanwhile, the advent of genomic studies holds the possibility of opening many more research and treatment frontiers.

\section{Conclusion}

Amish medical genetic studies has come a long way since the early 1960s, but the emergence and early years of inquiry suggest a number of features that have remained persistent aspects of the work and continue to model positive patterns for the present and the future. The work was, first of all, broadly cooperative, relational, and interdisciplinary. Medical doctors, geneticists, medical sociologists, anthropologists, and public health practitioners collaborated and worked together. Scholars of Amish studies who continue to draw on pioneering demography and directories are indebted as much to a cardiologist and an ophthalmologist as they are to traditional social scientists and statisticians.

Perhaps more important is the sort of cooperation represented by the mutuality that seems to have existed between patients, practitioners, and researchers, and between the Amish community generally and the academic community. Cultural concerns were taken seriously and the involvement of liaisons such as Fisher and Riehl were crucial. Demographic data, in the form of settlement directories, was returned to communities that then decided when and how to distribute and, ultimately, revise and reissue them.

Cooperation and mutuality were present at the start; may they continue to be in the future.

\section{Appendix: Brief Definitions of Select Terms and Conditions Mentioned in This Article}

For more information, see the National Institutes of Health's online National Library of Medicine, https://ghr.nlm.nih.gov/.

Achondroplasia: An autosomal dominant disorder related to bone development, resulting in short stature and limbs, often accompanied by other skeletal disorders, such as curvature of the spine.

Atrial septal defect: A birth defect in which there is a hole in the wall that divides the upper chambers of the heart.

Autosomal dominant: One copy of a mutation, from either parent, is enough to cause the disease in offspring; autosomal refers to any gene on a non-sex chromosome.

Autosomal recessive: Two copies of a mutation, from both mother and father, must be present in the offspring to cause the disease; autosomal refers to any gene on a non-sex chromosome.

Cartilage-hair hypoplasia: An autosomal recessive disorder related to bone development, resulting in short stature and limbs; characteristics also include fine, sparse hair and compromised immune system function.

Ellis-van Creveld syndrome: An autosomal recessive disorder related to bone development, resulting in short stature and limbs; characteristics also include polydactyly and heart defects. 
Limb-girdle muscular dystrophy: A condition that reduces muscle strength around shoulders or hips or both. Some forms of limb-girdle muscular dystrophy are autosomal recessive.

Phenylketonuria: An autosomal recessive disorder in which the body does not properly metabolize the amino acid phenylalanine; untreated, the condition can lead to intellectual and other disabilities.

Polydactyly: A condition in which an individual has more than five fingers per hand or five toes per foot.

\section{References}

Amish Farm and Home Directory. [Gordonville, PA]: The Committee, 1965.

Christner, Levi D., comp. Old Order Amish Church Districts of Indiana. LaGrange, IN: Waddell Printing, 1949.

Cross, Harold E. "Genetic Studies in an Amish Isolate." PhD diss., Johns Hopkins University, 1967.

—, ed. Ohio Amish Genealogy, Holmes County and Vicinity. Baltimore: Division of Medical Genetics, Johns Hopkins University School of Medicine, 1967.

Cross, Harold E., and Andrew H. Crosby. "Amish Contributions to Medical Genetics." Mennonite Quarterly Review 82 (July 2008): 449-67.

Cross, Harold E., and Eli E. Gingerich, comps. Indiana Amish Directory: Elkhart and LaGrange Counties. Baltimore: Division of Medical Genetics, The Johns Hopkins University School of Medicine, 1970.

Cross, Harold E., and Ervin Gingerich, comps. Ohio Amish Directory: Holmes County and Vicinity. Baltimore: Division of Medical Genetics, Johns Hopkins University School of Medicine, 1965; corrected reprint, 1966.

Cross, Harold E., and Beulah Stauffer Hostetler, eds. Index to Selected Amish Genealogies. Baltimore: Division of Medical Genetics, Johns Hopkins University School of Medicine, 1970.

Cross, Harold E., and Victor A. McKusick. “Amish Demography.” Social Biology 17, no. 2 (1970): 83-101. https://doi.org/10.1080/19485565.1970.9987850

Donnermeyer, Joseph. "Of Shoulders and Shadows: Selected Amish Scholarship before 1963." Journal of Amish and Plain Anabaptist Studies 5, no. 2 (2017): 162-95. https://doi.org/10.18061/1811/81527

Egeland, Janice A. "Belief and Behavior as Related to Illness: A Community Case Study of the Old Order Amish.” PhD diss., Yale University, 1967.

—, ed. Descendants of Christian Fisher and Other Amish-Mennonite Pioneer Families. Baltimore: The Moore Clinic, Johns Hopkins University School of Medicine, 1972.

Fisher, Sara E. The Amish School. People's Place Booklet No. 6. Intercourse. With Rachel K. Stahl. PA: Good Books, 1986. 
Francomano, Clair A. "Victor A. McKusick and Medical Genetics among the Amish." In Victor McKusick and the History of Medical Genetics, edited by Krishna R. Dronamraju and Clair A. Francomano, 119-30. New York: Springer, 2012.

https://doi.org/10.1007/978-1-4614-1677-7_13

Francomano, Clair A., Victor A. McKusick, and Leslie Biesecker. "Medical Genetic Studies in the Amish: Historical Perspectives." American Journal of Medical Genetics, Part C, 121C, no. 1 (2003):1-4. https://doi.org/10.1002/ajmg.c.20001

Free, Alfred H., and Helen M. Free. "Self-Testing, an Emerging Component of Clinical Chemistry." Clinical Chemistry 30, no. 6 (1984): 829-38.

https://doi.org/10.1093/clinchem/30.6.829

Hostetler, John A. Amish Society. Baltimore: Johns Hopkins University Press, 1963.

Jackson, Charles E., and Joshua H. Carey. "Progressive Muscular Dystrophy: Autosomal Recessive Type." Pediatrics 28, no. 1 (July 1961): 77-84.

Juberg, Richard C. "Selection in the ABO, Rhesus, and MNSs Blood Group Polymorphisms in an Amish Isolate of Northern Indiana.” PhD diss., University of Michigan, 1966.

Lindee, Susan M. Moments of Truth in Genetic Medicine. Baltimore: Johns Hopkins University Press, 2005.

Martin, Paul H. "PKU: A Casefinding Project." Children 11, no. 3 (May-June 1964): 123-24.

McKusick, Victor A., ed. Medical Genetic Studies of the Amish: Selected Papers. Baltimore: Johns Hopkins University Press, 1978.

McKusick, Victor A., Janice A. Egeland, Roswell Eldridge, and David E. Krusen. "Dwarfism in the Amish, Part I: The Ellis-van Creveld Syndrome." Bulletin of the Johns Hopkins Hospital 115 (1964): 306-36.

McKusick, Victor A., John A. Hostetler, and Janice A. Egeland. "Genetic Studies of the Amish: Background and Potentialities.” Bulletin of the Johns Hopkins Hospital 115 (1964): 203-22.

McKusick, Victor A., John A. Hostetler, Janice A. Egeland, and Roswell Eldridge. "The Distribution of Certain Genes in the Old Order Amish." Cold Spring Harbor Symposia on Quantitative Biology 29 (1964): 99-114. https://doi.org/10.1101/SQB.1964.029.01.015

McKusick, Victor A., Roswell Eldridge, John A. Hostetler, Utai Ruangwit, and Janice A. Egeland. "Dwarfism in the Amish, Part II: Cartilage-Hair Hypoplasia." Bulletin of the Johns Hopkins Hospital 116 (1965): 285-326.

Ohio Amish Directory. [Millersburg, OH: E. N. Gingerich], 1960. 